Non-typhoidal Salmonella (NTS) is an important pathogen that causes gastroenteritis, bacteraemia, and focal infections. Herein, we present our experience with bloodstream infections caused by Salmonella in paediatric leukaemia patients, which has been reported for the first time in both Europe and the US. According to our research, NTS might be a cause of serious infections in paediatric haematology-oncology patients. Following a low bacterial diet and increasing the hygiene of both the children and their surroundings would be beneficial in preventing these infections.

Key words: acute lymphoblastic leukaemia, non-typhoidal salmonellosis, neutropaenia.

Contemp Oncol (Pozn) 2018; 22 (2): 105-107 DOI: https://doi.org/10.5114/wo.2018.76446

\section{Non-typhoidal Salmonella bacteraemia in paediatric leukaemia patients}

\author{
Yöntem Yaman ${ }^{1}$, Ilker Devrim², Gulcihan Ozek³ ${ }^{3}$ Bengü Demirağ ${ }^{4}$, \\ Yeşim Oymak ${ }^{3}$, Gamze Gülfidan ${ }^{5}$, Canan Vergin ${ }^{3}$
}

${ }^{1}$ Department of Paediatric Haematology, Medipol University Hospital, İstanbul, Turkey ${ }^{2}$ Department of Paediatric Infectious Diseases, Dr. Behçet Uz Children's Hospital, İzmir, Turkey

${ }^{3}$ Department of Paediatric Haematology, Dr. Behçet Uz Children's Hospital, İzmir, Turkey ${ }^{4}$ Department of Paediatric Oncology, Dr. Behçet Uz Children's Hospital, İzmir, Turkey ${ }^{5}$ Department of Clinical Microbiology, Dr. Behçet Uz Children's Hospital, İzmir, Turkey

\section{Introduction}

Infections are the leading cause of morbidity and mortality in paediatric cancer patients. Paediatric cancer patients have an increased tendency for infections due the effect of specific chemotherapeutics', their neutropaenic state, and underlying malignant disease [1]. Bloodstream infections (BSI) form the majority of these infections. In children with leukaemia, only $30-40 \%$ of the microbial causes of infections have been identified microbiologically [1, 2]. The distribution of BSIs may change from one centre to another. Some authors have reported the predominance of Gram-negative bacteria along with Gram-positive bacteria [1, 3]. The most commonly isolated Gram-negative pathogens are Pseudomonas aeruginosa, Klebsiella pneumoniae, and Escherichia coli [1,3]. The Salmonella species have rarely been reported in English literature as a causative agent of febrile neutropaenia in children.

Herein, we present our experience with bloodstream infections caused by Salmonella in paediatric leukaemia patients, which has been reported for the first time in both Europe and the US.

\section{Material and methods}

This retrospective study was designed to evaluate Salmonella bacteraemia cases in febrile patients who were hospitalised at the Paediatric Haematology-Oncology and Infectious Disease units of Dr. Behçet Uz Children's Hospital for treatment of malignancies from December 2008 to February 2014. The medical records and computerised microbiology laboratory records of 162 children with acute lymphoblastic and acute myeloblastic leukaemia who were hospitalised at the Department of Paediatric Haematology-Oncology and Infectious Disease in Dr. Behçet Uz Children's Hospital were reviewed to identify patients who were diagnosed with salmonellosis.

Data on demographics, chemotherapy, symptoms, details of treatment, culture results, antimicrobial sensitivity data of the cultures, delay of chemotherapy, and outcome were recorded. Empiric therapy with broad-spectrum antibiotics was initiated upon the presence of fever (defined as a temperature $\geq 38^{\circ} \mathrm{C}$ on two occasions within a 12 -hour period or a single measurement $\geq 38.3^{\circ} \mathrm{C}$ ) during neutropaenia. Two blood cultures, one from peripheral veins and one through ports, were taken according to our infection control procedure from each patient who presented with a fever. Blood samples were aseptically collected for blood cultures in paediatric blood culture bottles (BacT/Alert PF - Biomerieux-France) from all the study patients. Each bottle contained 1-3 $\mathrm{ml}$ of blood and was incubated at $37^{\circ} \mathrm{C}$ for up to seven days. Once a positive culture bottle was detected, a Gram stain slide was prepared from the bot- 
tle along with a subculture of a loopful of the positive blood culture bottle contents on blood agar, EMB agar, Chocolate agar, and Sabouraud agar (Salubris-Turkey) followed by incubation at $37^{\circ} \mathrm{C}$ for $18-24$ hours. If non-lactose fermenting colonies were detected, then biochemical identification tests were performed using a VITEK II automated system (Biomerieux-France). Final identification of isolates was confirmed serologically according to the Kauffman-White classification using "RSHM" Salmonella antisera (Turkey). Antibiotic susceptibility testing was performed on pure culture using the broth dilution method by VITEK II automated microbiology system. The following antibiotics were tested: amikacin, ampicillin, gentamicin, meropenem, netilmicin, piperacillin, cefepime, cefoxitin, ceftazidime, ceftriaxone, cefuroxime, ciprofloxacin, amoxicillin-clavulanate, imipenem, trimethoprim/sulfamethoxazole, and tigecycline. The results were interpreted using the Clinical and Laboratory Standards Institute (CLSI) standards. Sensitivity results were then reported as sensitive or resistant based on the CLSI criteria [4].

\section{Results}

Between October 2008 and February 2014, seven children with acute leukaemia had suffered from non-typhoidal Salmonella (NTS)-associated bacteraemia. Among them four had associated positive stool cultures. Six of the patients were neutropaenic (85.7\%), while one was not. The demographic/clinical features are reviewed in Table 1. The median age was four years (ranging from two years to 10 years). Six patients (85.7\%) were male, while one (14.3\%) was a female. All but one of the children, in whom the family refused treatment, was receiving chemotherapy during the course of the NTS infection. Among the six other patients, two were receiving induction chemotherapy, one was receiving reinduction therapy, and three were on maintenance chemotherapy according to the ALL-BFM protocol (Table 1).

All of the children with NTS bacteraemia had associated diarrhoea. They had all been hospitalised and received broad-spectrum antibiotics after samples for blood cultures were obtained (Table 1). Modification of antibiotics was done in four of the patients after blood culture or clinical deterioration. All of the patients recovered from NTS BSI without any complications including typhlitis or surgical complications. However, five of the patients had their chemotherapy delayed for at least seven days (ranging from seven to 18 days).

The Salmonella species isolated from the patients were as follows: Salmonella ssp. (3), Salmonella group D (2) and Salmonella enterica ssp. arizonae (2). All the NTS species were susceptible to ceftriaxone and fluoroquinolones. The resistance to individual antimicrobials was found at vary-

Table 1. Demographic/clinic characteristics of the patients

\begin{tabular}{|c|c|c|c|c|c|c|c|c|c|c|c|}
\hline $\begin{array}{c}\text { Age } \\
\text { (years) }\end{array}$ & Gender & $\begin{array}{l}\text { Primary } \\
\text { diagnosis }\end{array}$ & $\begin{array}{l}\text { Treatment } \\
\text { phase at } \\
\text { time of } \\
\text { infection }\end{array}$ & $\begin{array}{l}\text { Total } \\
\text { leucocyte } \\
\text { count } \\
\text { (number/ } \\
\mathrm{mm}^{3} \text { ) }\end{array}$ & $\begin{array}{l}\text { Absolut } \\
\text { neutrophil } \\
\text { count } \\
\text { (number/ } \\
\mathrm{mm}^{3} \text { ) }\end{array}$ & Complaints & $\begin{array}{c}\text { Antibiotics } \\
\text { usage (days) }\end{array}$ & $\begin{array}{l}\text { Modification } \\
\text { of antibiotics } \\
\text { (days) }\end{array}$ & $\begin{array}{l}\text { Delay } \\
\text { of } \\
\text { chemo- } \\
\text { therapy } \\
\text { (days) }\end{array}$ & $\begin{array}{l}\text { Culture } \\
\text { results }\end{array}$ & $\begin{array}{l}\text { Culture } \\
\text { obtained } \\
\text { from }\end{array}$ \\
\hline 2 & $\mathrm{~F}$ & B-ALL SRG & Induction & 65,000 & 1,550 & Diarrhoea & Pip-taz (10) & NR & None & $\begin{array}{c}\text { Salmonella } \\
\text { spp. }\end{array}$ & $\begin{array}{l}\text { Blood, } \\
\text { porta- } \\
\text { cath }\end{array}$ \\
\hline 3 & $M$ & B-ALL SRG & $\begin{array}{l}\text { Mainte- } \\
\text { nance }\end{array}$ & 680 & 60 & $\begin{array}{c}\text { Fever, } \\
\text { diarrhoea, } \\
\text { arthralgia }\end{array}$ & $\begin{array}{l}\text { Pip-taz (14) } \\
\text { Metronid (7) }\end{array}$ & $\begin{array}{l}\text { Imipenem } \\
\text { (5) } \\
\text { Amikacin (7) }\end{array}$ & 7 & $\begin{array}{c}\text { Salmonella } \\
\text { spp. }\end{array}$ & $\begin{array}{c}\text { Blood, } \\
\text { stool }\end{array}$ \\
\hline 10 & M & $\begin{array}{c}\text { B-ALL } \\
3^{\text {rd }} \text { relapse }\end{array}$ & $\begin{array}{c}\text { Refractory } \\
\text { disease }\end{array}$ & 11,800 & 880 & $\begin{array}{c}\text { Fever, } \\
\text { diarrhoea, } \\
\text { vomiting }\end{array}$ & Pip-taz (14) & NR & $\begin{array}{l}\text { Not } \\
\text { under } \\
\text { treat. }\end{array}$ & $\begin{array}{l}\text { Salmonella } \\
\text { group D }\end{array}$ & $\begin{array}{l}\text { Blood, } \\
\text { porta- } \\
\text { cath }\end{array}$ \\
\hline 4 & M & B-ALL SRG & $\begin{array}{l}\text { Mainte- } \\
\text { nance }\end{array}$ & 680 & 60 & $\begin{array}{c}\text { Fever, } \\
\text { diarrhoea }\end{array}$ & Pip-taz (7) & $N R$ & 7 & $\begin{array}{c}\text { Salmonella } \\
\text { enterica } \\
\text { ssp. } \\
\text { arizonae }\end{array}$ & $\begin{array}{c}\text { Blood, } \\
\text { stool }\end{array}$ \\
\hline 4 & $M$ & B-ALL HRG & Reinduction & 880 & 50 & $\begin{array}{c}\text { Fever, } \\
\text { diarrhoea }\end{array}$ & $\begin{array}{l}\text { Pip-taz (8) } \\
\text { Metronid (7) }\end{array}$ & $\begin{array}{c}\text { Meronem } \\
(10 \mathrm{~d}) \\
\text { Amikacin (7) }\end{array}$ & 18 & $\begin{array}{c}\text { Salmonella } \\
\text { enterica } \\
\text { ssp. } \\
\text { arizonae }\end{array}$ & $\begin{array}{l}\text { Blood, } \\
\text { stool }\end{array}$ \\
\hline 9 & M & $\begin{array}{l}\text { B-ALL } \\
\text { relapse }\end{array}$ & Induction & 100 & 20 & $\begin{array}{c}\text { Fever, } \\
\text { diarrhoea }\end{array}$ & $\begin{array}{l}\text { Meropenem } \\
\quad(10) \\
\text { Metronid (7) }\end{array}$ & $\begin{array}{l}\text { Vanco (10d) } \\
\text { Amikacin (7) }\end{array}$ & 15 & $\begin{array}{l}\text { Salmonella } \\
\text { group D }\end{array}$ & Blood \\
\hline 10 & M & $\begin{array}{c}\text { B-ALL } \\
2^{\text {nd }} \text { relapse }\end{array}$ & $\begin{array}{c}\text { Waiting for } \\
\text { BMT, } \\
\text { mainte- } \\
\text { nance }\end{array}$ & 900 & 300 & $\begin{array}{c}\text { Fever, } \\
\text { diarrhoea, } \\
\text { arthralgia }\end{array}$ & $\begin{array}{c}\text { Pip-taz (10) } \\
\text { Amikacin } \\
(10)\end{array}$ & $\begin{array}{c}\text { Meronem } \\
(21) \\
\text { Vanco (14) }\end{array}$ & 14 & $\begin{array}{c}\text { Salmonella } \\
\text { spp. }\end{array}$ & $\begin{array}{c}\text { Blood, } \\
\text { stool }\end{array}$ \\
\hline
\end{tabular}

B-ALL - B-cell acute lymphoblastic leukaemia, SRG - standard-risk group, HRG - high-risk group, BMT-bone marrow transplant, Pip-taz-piperacillin-tazobactam, Metronid - metronidazole, Vanco - vancomycin, NR - not required, treat. - treatment 
ing rates: ampicillin in two isolates (28.5\%), nitrofurantoin in two isolates (28.5\%), and amikacin in one isolate (14.5\%).

\section{Discussion}

Non-typhoidal Salmonella species mainly cause self-limiting enterocolitis in immunocompetent individuals [5]. However, approximately $5 \%$ of these patients were reported to develop secondary bacteraemia, which was associated with a low mortality ratio, ranging between 1 and 5\% [5, 6]. The risk of invasive infections with non-typhoidal species was generally associated with inherited or acquired immunodeficiency syndromes. In one study invasive disease was reported to occur in up to $47 \%$ of immunocompromised infants in Africa [7].

Since oncology-haematology patients were under intensive chemotherapy, the paediatric cancer patients were supposed to have invasive infections due to NTS. However, there are only two articles present in the English literature in which infections due to Salmonella species are reported. In one case series from Pakistan, Salmonella paratyphi $B$ was reported as the most commonly isolated organism in paediatric neutropaenic febrile children [3]. Moreover, in one case report from India; a five-year-old male child who had developed Salmonella typhi arthritis of his left hip during neutropaenic phase was presented [8]. In one study from Spain, among 29 cases of NTS bacteraemia, three children with malignancy were present [9]. In one study from Poland, among a total of 30 adult patients with NTS, 12 of the patients had a malignancy [10]. Two of the patients with malignancy died due to NTS infection. To our knowledge this is the first case series of NTS as a causative agent of bacteraemia in paediatric malignancy patients. The transmission of NTS generally happens when people eat contaminated foods of animal origin such as meat or eggs. They can also be infected by ingesting organisms in animal faeces, either directly or in contaminated food or water. According to our observations, our patients and their parents did not strictly comply with a low-bacteria diet and generally preferred consuming foods from local traditional restaurants. Although for now there is no evidence for the benefits of low-bacteria diet in children and adults for the prevention of infection and related complications, our experience with NTS infections supports the assumption that a low-bacteria diet would be beneficial in preventing food-borne infections in neutropaenic patients [11]. The definition of a neutropaenic or low-bacteria diet is controversial; however, commonly prohibited foods are raw fresh fruits and vegetables. To reduce the risk of foodborne diseases, raw or undercooked eggs, poultry, and other meats should be avoided. Unpasteurised milk and other dairy products should not be consumed.

Raw vegetables should be correctly washed before consumption [12]. Children under 10 years old seem to be particularly susceptible to severe salmonellosis after contact with reptiles [12].

Any anatomical site may be seeded haematogenously by NTS and may evolve into a local infection even if the bacteraemia is successfully treated [5]. Salmonella can cause focal suppurative infections of almost any organ [9].
A retrospective review of NTS bacteraemia cases showed that approximately one in six patients had obvious risk factors for salmonellosis; it was noted that seven of 25 immunocompromised children developed a focal infection [6]. In our clinic we have not experienced any complications during or after therapy.

In conclusion, as a foodborne agent, NTS might cause serious infections in paediatric haematology-oncology children. Low-bacteria diet and increasing the hygiene of children and their surroundings would be beneficial in preventing infections in neutropaenic children with these kinds of pathogens.

\section{The authors declare no conflict of interest.}

\section{References}

1. Bakhshi S, Padmanjali KS, Arva LS. Infections in childhood acute lymphoblastic leukemia: an analysis of 222 febrile neutropenic episodes. Pediatr Hematol Oncol 2008; 25: 385-392.

2. Katsibardi K, Papadakis V, Charisiadou A, Pangalis A, Polychronopoulou S. Blood stream infections throught the entire course of acute lymphoblastic leukemia treatment. Neoplasma 2011; 58: 326-330.

3. Bhatti FN, Burney IA, Moid MI, Siddiqui T. Bacterial isolates from neutropenic febrile pediatric patients and their sensitivity patterns to antibiotics. J Pak Med Assoc 1998; 48: 287-290.

4. Clinical and Laboratory Standards Institute. Performance Standards for Antimicrobial Susceptibility testings. Fifteenth Informational Supplement. CLSI document M100-S15. Clinical and Laboratory Standards Institute, Wayne, PA 2005.

5. Hohmann EL. Nontyphoidal salmonellosis. Clin Infect Dis 2001; 32: 263-269.

6. Zaidi E, Bachur R, Harper M. Non-typhi Salmonella bacteremia in children. Pediatr Infect Dis J 1999; 18: 1073-1077.

7. Wittler RR, Bass JW. Nontyphoidal salmonella enteric infections and bacteremia. Pediatr Infect Dis J 1989; 8: 364-367.

8. Naithani R, Rai S, Choudhry VP. Septic arthritis of hip in a neutropenic child caused by Salmonella typhi. J Pediatr Hematol Oncol 2008; 30: 182-184.

9. Díez Dorado R, Tagarro García A, Baquero-Artigao F, García-Miguel MJ, Uría González MJ, Peña García P, del Castillo Martín F. Non-typhi Salmonella bacteremia in children: an 11-year review. An Pediatr (Barc) 2004; 60: 344-348.

10. Kedzierska J, Beata PJ, Kedzierska A. Clinical Presentation of Extraintestinal Infections Caused by Non-Typhoid Salmonella Serotypes Among Patients at the University Hospital in Cracow During an 7-year Period. Pol J Microbiol 2008; 57: 41-47.

11. Fox N, Freifeld AG. The neutropenic diet reviewed: moving toward a safe food handling approach. Oncology (Williston Park) 2012; 26: 572-575.

12. Non typhoidal salmonellosis. Center for food security and Public Health, lowa State Hospital. http://www.cfsph.iastate.edu/diseaselnfo/notes/salmonellosisnontyphoidal.pdf.

\section{Address for correspondence}

\section{Yöntem Yaman}

Department of Pediatric Hematology

Medipol University Hospital

Göztepe Mahallesi, Metin Sk. No: 4

34214 Bağcılar/istanbul, Turkey

e-mail: yontemyaman@gmail.com

Submitted: 12.03 .2018

Accepted: $\quad 27.05 .2018$ 